\title{
Luiz CARlos NogueIRA: PSICANÁLISE NO IP-USP E NO BRASIL
}

\author{
Departamento de Psicologia Clínica \\ Instituto de Psicologia - USP
}

\begin{abstract}
$\mathrm{N}_{\mathrm{cos}}^{\mathrm{cos}}$ esta edição especial da Revista Psicologia USP, em que seu corpo editorial tomou a decisão de fazer um volume temático dedicado ao Professor Luiz Carlos, o Departamento de Psicologia Clínica indicou alguns professores, dentre os que puderam conviver com o colega por mais tempo ou de forma mais intensa, para, em nome do Departamento, situá-lo histórica e academicamente de maneira a que outros colegas, que tiveram com ele menos tempo de convívio, pudessem compartilhar dos sentimentos de orgulho de nosso Departamento pelo justo reconhecimento público que lhe é outorgado com essa homenagem.

Luiz Carlos Nogueira entrou na Faculdade de Filosofia Nossa Senhora Medianeira, em Nova Friburgo no Estado do Rio, em 1955. Obteve a licenciatura em Letras Clássicas em 1960 e a licenciatura em Filosofia em 1961.

Nesse período de formação, despertou para a importância dos fundamentos das ciências e suas relações com a Filosofia, bem como para a riqueza do pensamento grego. Iniciou, também, o estudo da Psicologia Experimental e da Psicologia Científica em geral.

A partir de 1960, decidiu continuar seus estudos de Psicologia, começados na formação básica, principalmente de Psicanálise. Assim, em 1961, entrou no Curso de Especialização em Psicologia Clínica da Faculdade de Filosofia, Ciências e Letras da USP, sob a responsabilidade da Profa. Annita de Castilho e Marcondes Cabral e dirigido pelo Prof. Durval Marcondes e sua equipe de psicanalistas.
\end{abstract}


Definindo-se pela Psicanálise e pela Psicoterapia, desenvolveu, durante o Curso, trabalho intenso no tratamento de crianças, principalmente. Iniciou sua pesquisa em Psicoterapia, que resultou na sua Dissertação de Mestrado, defendida em 1970 no Instituto de Psicologia da USP, já que o Curso de Especialização fora transformado em Curso de Pós-Graduação e propic iava a obtenção do título acadêmico de Mestre. A Dissertação foi elaborada a partir de um caso grave de criança, tratada durante quatro anos, segundo a técnica psicanalítica. Seguia, então, a orientação kleiniana.

Nessa época (1962), considerando que fazia parte da formação, iniciou sua análise pessoal com um analista indicado pela Sociedade Brasileira de Psicanálise de São Paulo, durante cinco anos e com quatro sessões semanais. Renovou sua análise pessoal em 1973, agora com um analista de orientação lacaniana.

Uma vez começada a formação psicanalítica e a sua pesquisa, foi surgindo para ele um caminho diferente que vinha satisfazer às questões levantadas durante o Curso de Pós-Graduação e, principalmente, depois da leitura de Paul Ricoeur. A problemática se a Psicanálise poderia ser uma ciência, levou-o a entrar em contato com o texto de Ricoeur ' $L$ ' Interpretation, essai sur Freud", onde encontrou respostas e, principalmente, a abertura para a obra de Jacques Lacan.

A pesquisa, na leitura da obra de Freud, resultou na sua Tese de Doutorado, defendida em 1973, no Instituto de Psicologia da USP. O título Contribuição ao Estudo Crítico do Inconsciente Freudiano indica que a Psicanálise agora era vista por ele como proposta original para um novo campo da Psicologia Humana. O inconsciente como objeto de uma nova ciência, que exigia uma metodologia também nova, diferente de tudo que se fizera desde Galileu. A Psicologia, como ciência do comportamento, não podia servir de método para o estudo dos atos falhos, da decifração da linguagem inconsciente. O sonho e os sintomas, apresentando um sentido, exigiam uma perspectiva nova para a compreensão do homem.

Em outubro de 1974, apresentou um trabalho sobre um caso, agora segundo a teoria lacaniana no $1^{\circ}$ Congresso Interamericano de Psicologia 
Clínica, realizado em Porto Alegre. Em 1975, conseguiu realizar, em São Paulo, o $1^{\circ}$ Encontro Nacional de pessoas interessadas na obra de Lacan, onde pôde trocar informações sobre pesquisas afins. Fundava, então, o Centro de Estudos Freudianos (CEF), o primeiro círculo lacaniano do Brasil, junto com outros dois colegas, também psicanalistas.

$\mathrm{Na}$ mesma época, vinha desenvolvendo com os alunos do $5^{\circ}$ ano do Curso de Psicologia e com outros profissionais, um grupo de estudos que iniciou a leitura dos Écrits de Lacan. Em fevereiro de 1976, realizou o $2^{\circ}$ Encontro Nacional, agora com um número muito maior de participantes, inclusive de profissionais que haviam se formado recentemente na França.

Participou das atividades de várias instituições psicanalíticas de orientação lacaniana, tornando-se uma figura muito importante para o ensino e difusão da obra de Lacan, não só na Universidade como também no Brasil.

Iniciou seu magistério na USP em 1969, a convite do Prof. Durval Marcondes, como instrutor junto ao Setor de Psicologia Clínica da Faculdade de Filosofia, Ciências e Letras. Em 1970, com a criação do Instituto de Psicologia, foi contratado como auxiliar de ensino junto ao Departamento de Psicologia Clínica, ministrando as disciplinas "Ludoterapia" e "Psicoterapia de adultos" para os alunos do $5^{\circ}$ ano da Graduação.

Em 1975, com a criação do Programa de Pós-Graduação em Psicologia, área de concentração Psicologia Clínica, do IP-USP, começou seu trabalho de orientações de dissertações e teses. Com esse trabalho, ajudou na formação de novas gerações de pesquisadores no campo psicanalítico.

A partir de 1976, e ininterruptamente, ministrou disciplinas na PósGraduação, cujo conteúdo sempre esteve diretamente ligado aos textos lacanianos e às suas pesquisas desenvolvidas no campo da Psicanálise. Na Graduação, durante duas décadas, também ministrou o ensino de Lacan, em disciplina optativa, para os alunos dos últimos semestres.

Em 1997, defendeu sua Tese de Livre-Docência, A Psicanálise: Uma Experiência Original - O Tempo de Lacan e a Nova Ciência, no Instituto de Psicologia. Esse trabalho surgiu como resultado de anos de ensino, de pesquisas e de atendimento de clientes em Psicanálise. 
Assumiu, por diversas vezes, a função de vice-chefe do Departamento de Psicologia Clínica e, entre 1995 e 1997, a da chefia. Participou, em várias ocasiões, do Conselho Departamental e da Comissão de Pós-Graduação do Departamento.

Seus trabalhos como docente universitário, psicanalista e pesquisador trouxeram contribuições valiosas para as atividades desenvolvidas no Departamento, não só pela introdução do ensino de Lacan na Universidade, como também pela dedicação e empenho que sempre teve na formação dos alunos, seja como pesquisadores, seja para o exercício da atividade clínica. Podemos assinalar, sem sombra de dúvidas, que ele foi uma figura de destaque do Departamento de Psicologia Clínica e do Instituto de Psicologia da Universidade de São Paulo.

Embora atravessados pelo pesar decorrente de sua ausência, os frutos de seu trabalho permanecem entre nós por meio dos rumos clínicos e acadêmicos tomados e preservados por nosso Departamento, os quais o Prof. Luiz Carlos Nogueira, ao longo dos anos, ajudou a estabelecer. As suas reflexões sobre a Ética, como elemento fundante de toda atividade clínica, assim como o seu pensamento marcado pelo rigor conceitual e crítico, permanecem entre nós, seus colegas, e também com os diversos pesquisadores que ele ajudou a formar. 